\title{
«ГІБРИДНА ВІЙНА» РОСІЇ ПРОТИ УКРАЇНИ: ІНФОРМАЦІЙНИЙ АСПЕКТ
}

Досліджуеться природа російсько-української «гібридної війни». Не торкаючись суто військових та збройних аспектів конфлікту, висвітлюеться інформаційна складова «гібридної війни», що в рамках воєн четвертого покоління стала однією із визначальних чинників протиборства між агресором і країною, яка зазнала нападу. Особливий акцент робиться на дослідженні: особливостей пропагандистських механізмів з двох боків російсько-українського конфлікту; зіставленні комунікативно-пропагандистських можливостей сторін; роботи 3 масовою аудиторією; помилок інформаційної політики в період російсько-українського конфлікту.

Ключові слова: російсько-українська війна, «гібридна війна», інформаційна війна, смислова війна, інформаційні технології.

Проблема «інформаційної війни», як i проблема «інформаційної зброї», вперше почали досліджуватися на початку 80-х років XX ст. Одним із перших авторів, який ще в 1976 р. запровадив термін «інформаційна війна» та ссрормулював 屰 основні причини вважається американський вчений Т. Рона [1, с. 398]. Сьогодні переважна більшість дослідників стверджують, що за сучасних умов може існувати дев'ять основних типів інформаційної війни як різновидностей «воєн нового покоління». Російсько-українську війну 2014-2015 pp. визначають у світі як приклад війни нового типу. У публікаціях, які присвячені подіям російсько-української війни, найчастіше вживаються терміни: 1) «гібридна війна»; 2) комбінована війна; 3) змішана війна; 4) неоконвенційна, нестандартна війна; 5) кримінальнотерористична війна; 6) війна керованого хаосу або нелінійна війна.

Гетьманчук Микола Петрович, доктор історичних наук, професор, завідувач кафедри українознавства, Львівський державний університет внутрішніх справ, м. Львів.

(C) Гетьманчук М.П., 2017 
Вітчизняна військово-теоретична думка щодо оцінки російсько-української війни знайшла своє відображення у статті колишнього секретаря Ради національної безпеки і оборони (РНБО) А.В. Парубія, яка з'явилася в Інтернеті у серпні 2014 р. Він, зокрема, подає наступну дефініцію: «Україна воює, і неоголошена війна, яка ведеться Росією проти нас, визначається, як "гібридна», "нелінійна», або «війна керованого хаосу». Така війна поєднує військові, інформаційні, терористичні та інші агресивні дії, скоординовані 3 єдиного центру i спрямовані на досягнення визначеної стратегічної мети. Метою цієї війни $є$ повне підпорядкування України експансіоністським планам Кремля [2]. Терміни, якими позначається російсько-українська війна, переважно $є$ близькими за значенням. Тому найбільшого поширення здобув термін «гібридна війна», який у широкому значенні охоплюе усі різновиди «воен нового покоління».

У цілому під «гібридною війною» вже традиційно розуміють такі військові дії, які є неоголошеними і під час яких протилежна сторона атакуе державні структури, регулярну армію та інші основні інститути противника за допомогою місцевих бунтівників i сепаратистів, підтримуваних зброєю i фрінансами з-за кордону та деякими внутрішніми структурами (олігархами, організованою злочинністю, кіберзлочинністю, націоналістичними та іншими організаціями). Як свідчить практика, такі війни ведуться не лише за певні території, а й за вплив на свідомість людей. Коментуючи саме «гібридну війну», фрахівці вважають, що вона $є$ сучасним видом партизанської війни, яка об'єднує сучасні технології, традиційні військові дії та нестандартні технології, $е$ формою воєнних дій із залученням до конфлікту різнорідних за складом, засобами, рівнем та характером підготовки озброєних сил [3, 12].

Усе це дає підстави вважати, що гібридна війна має низку відзнак, характерних саме для неї. Йдеться, в першу чергу, про інформаційні, психологічні, ідеологічні складові такої війни. Суто воєнні дії тут мають прихований характер. Кожна з вище вказаних складових 
такої війни несе свій зміст, але дуже часто вони між собою пов'язані. Наприклад, якщо інформаційна війна має свої завданням працювати 3 інформацією, то психологічна оперуе емоціями, але мета їх діяльності одна: вплинути на менталітет конкретної особи (групи осіб), надати особистісному світогляду необхідного, вигідного ініціатору конфлікту змісту. Причому інформаційну складову потрібно вважати основною, що дає змогу оцінювати їі навіть не складовою, а новою фромою введення таких дій, саме - інформаційною війною. Метою інфрормаційної війни є безпосередній психологічний вплив на людей для формування їхнього менталітету в необхідному напрямі [4, c. $14-15]$.

Аналіз подій російсько-української війни дозволяе виявити певні закономірності «війни гібридної». Президент України П. Порошенко, виступаючи на сесії Генеральної Асамблеї ООН, відзначив: «це не єдина «гібридна війна", яку розв'язувала Росія для того, щоб зберегти свій вплив у сусідніх країнах, Росія протягом багатьох десятиліть свідомо створювала навколо себе пояс нестабільності. Це Нагірний Карабах, Придністров'я, Абхазія, Південна Осетія, Крим, Донбас. Кремль йде далі, i в ці дні російські «зелені чоловічки» ступають на сирійську землю. Що або хто наступний? [5, с. 5]. На театрі воєнних дій Росія використала проти України ряд підривних соціальних технологій: 1) технологію поділу України на «народні республіки»; 2) технологію створення кримінального натовпу; 3) технологію заколоту i захоплення влади в містах; 4) технологію "референдуму»; 5) технологію «живого щита» та ін. Всі вони, як зазначають дослідники, характеризуються певними ознаками: схожістю цілей; стандартністю дій та засобів досягнення цілей; синхронністю проведення акцій у різних містах України; схожістю зовнішньої атрибутики, символіки, ідеологічного та пропагандистського забезпечення акцій [6, с. 189].

Для реалізацій на практиці вищеназваних підривних технологій Росія розпочала проти України широко масштабну інформаційну війну. Інформаційна експансія Росії 
базуеться на старих, а не нових для аудиторії смислах, на активацій й утриманні радянських ментальних конструкцій. Російське телебачення утримує ці конструкції для підтримки у віртуальній площині залежності людей від держави. Відповідні урядові структури Росії успішно проводять інформаційну політику за допомогою трьох федеральних телевізійних каналів. Роль телебачення для них залишаеться важливішою, аніж роль Інтернету. Ведучий ток-шоу на Першому телевізійному каналі П. Толстой і Д. Кисельов, генеральний директор «Росії сьогодні», які транслюються багатьма іноземними мовами два головних пропагандисти Кремля. Тільки фінансування Д. Кисельова, яке забезпечується особисто президентом В. Путіним, становить 300 млн доларів на рік. За даними «Української правди», у 2014 р. Росія витратила 721 млн доларів на пропаганду лише на каналах національного телебачення в Росії. До ціеї цифрии треба додати 202 млн доларів, виділених для інших каналів, таких як НТВ або Перший канал, а також 86,7 млн доларів для PIA «Новини» i 396 млн доларів для редакцій англійською, арабською та іспанською мовами [7, с. 88].

Зіставляючи комунікативно-пропагандистську діяльність Росії й України в умовах «гібридної війни», можна розмежувати низку принципових відмінностей базового, організаційного та комунікативного рівнів:

По-перше, Росія, визначаючи для себе масштабніші задачі, мала відповідні та складніші інформаційні завдання, а агресію у фізичному просторі корелювала в просторі інформаційному. Більшість російського населення отримує інформацію з федеральних телевізійних каналів, інформаційну політику яких формуе уряд. Російські федеральні канали 3 їх інформащійними програмами та політичними ток-шоу вільно транслювались в Україні, а під заборону вони потрапили лише під час активних військових дій Росії. В Україні представлено різні телеканали, суттевий вплив на які мають олігархивласники. Також в Україні немає ані газет, ані телеканалів, доступних для російського населення. 
По-друге, Росія мае едині центри прийняття рішень і добре вибудувану вертикаль управління федеральними каналами, а також досвід управління в кризових ситуаціях, наприклад, російсько-грузинської війни. Міністерство оборони Росії проводить конференції на теми інформаційних воєн, протидії кольоровим револющіям, «м'якій силі», що свідчить про принципове визнання військовими нових методів впливу. Крім того, Росія має доктрину "російського світу», яка налаштована на підтримку російськомовного населення за межами Росії. Україна немае такого типу зовнішньо-орієнтованої доктрини.

По-трете, Росія мала досвід інформаційних воєн на пострадянському просторі, найвідомішими 3 яких $\epsilon$ : декілька російсько-українських газових і торгових воєн, російсько-грузинська війна 2008 р., російсько-естонська кібервійна. Населення України знає російську мову, тому російський інформаційний продукт має принципово більше можливостей для поширення, ніж український. Слід зазначити й те, що населення України має спільну з Росією історію, а це значно полегшуе вплив на нього, оскільки "спільне» сприймаеться потужніше, ніж «відмінне» [8, с. 462-463].

Проблемою для російської пропаганди стала необхідність розвінчання тези про українців як про братній народ. Цю проблему російська пропагандистська машина вирішила просто: росіянам почали говорити про «неправильність» лише частини народу (так званих бандерівців) та нової влади (нелегітимна чи хунта). Однак після виборів президента України ідея нелегітимності зникла з пропагандистського вжитку без жодного пояснення. Тепер увесь акцент було перенесено на правильність дій тих, хто воюе на боці проросійських сил в Донбасі та Луганську. Той негатив, з яким раніше характеризували владу, тепер було перенесено на українських військових, які беруть участь в Антитерористичній операції. Задіяли навіть термін «карателі», запозичений з часів Другої світової війни. Коли йшлося про Крим, то пропаганда приділяла увагу 
легітимації як нової влади Криму, так і редерендуму про входження Криму до складу Російської Федерації (РФ). Тут Росія максимально використала як радянську, так i дореволюційну символіку.

При цьому був отриманий парадоксальний наслідок: російська комунікативно-пропагандистська кампанія була настільки агресивною, що навпаки відвернула від себе українських глядачів, які мали можливість на власні очі фіксувати ті відхилення від правди, на яких вона базувалася. Саме це, а також реалії перших місяців військового протистояння (безпорадність українських військових або тих, хто ними керував, дивна неспроможність українського телебачення щодо спростування відвертої брехні російських телеканалів) мали зворотну дію - сприяли формуванню української політичної нації. Захищати незалежність України пішли масово як українці, так і росіяни. Тобто якщо для росіян ця військова компанія спрацювала на підняття рейтингу В. Путіна, то для українців вона спрацювала дивним чином навпаки: на падіння рейтингу В. Путіна та підняття почуття їх власної гідності. Використання всіх символів, якими російське телебачення описувало ситуацію в Україні (фашисти, бандерівці, неонацисти, хунта, нелегітимний уряд), з одного боку, було сприйнято з довірою більшою частиною населення Росії, але цілком підірвало довіру в населення України, бо не відповідало її реаліям.

Одним із наслідків "гібридної війни» стала активація якщо не імперського, то квазіімперського мовлення в Росіі, оскільки саме на ньому базується експертне середовище, яке забезпечувало підтримку війни. В Україні, навпаки, було активовано широким загалом громадян антиімперське телерадіомовлення. Радянський Союз лише умовно можна визначати як імперію, а от відхід від Радянського Союзу, саме заборона в Україні російського інформаційного і віртуального продукту - $€$ безпосереднім прощанням 3 імперією. До початку військових дій в Україні у більшості споживали російський інформаційний та віртуальний продукт. Він ніс і відповідну модель світу. Розрив із цією російською 
моделлю за відсутності адекватної власної матиме негативні наслідки, але цей процес Україна рано чи пізно повинна пройти. Українська держава повинна саме зараз вкладати кошти у створення власного інформаційного продукту, що відповідатиме новим вимогам. Він повинен бути: а) інтелектуальним; б) різножанровим; в) нести власну модель світу; г)давати відповіді на власні, а не чужі проблеми [8, с. 465].

Практика засвідчила, що успішність впливу російських телеканалів на свою аудиторію була максимальною. Схвалення діяльності В. Путіна досягло граничних висот. Але це виявилося максимальним програшем для Росії щодо українських глядачів, оскільки вони бачили в подачі російських телеканалів дуже істотне спотворення дійсності. Так, Росія обрала для характеристики ключових об'єктів свого опису подій російсько-української війни такі формалізовані засоби подачі інформацій: 1) часів Другої світової війни («бандерівці», «фрашисти», «карателі», «каральні війська») або ï відгомону у сьогоденні («неонацисти»); 2) радянських часів («возз'єднання Криму», «Крим наш»); 3) що відображали «законність» донецьких та луганських протестувальників проти київської влади («народний мер», «народний губернатор», «народний референдум»); 4) що відображали незаконність влади («нелегітимна влада», "самопроголошені керівники», «хунта»). Наприклад, мер, обраний на площі без жодних юридичних процедур, ставав «народним», џим начебто й забезпечувалася його легітимність. А те, що у цього мера може бути російський паспорт, уже нікого не хвилювало.

Україна, діючи за подібним сценарієм, також, своєю чергою, продукувала подібні посилання: 1) задіяність Росії («проросійські сили»); 2) «терористи», що дозволяло підвести під загальносвітову практику боротьби 3 тероризмом, як це свого часу зробила Росія в боротьбі 3 чеченським сепаратизмом; 3) «бандити», «бойовики» для характеристики свого противника, але це обмежувало розуміння того, що серед них $є$ мобілізовані новою «народною» владною, які виступають проти російської 
агресії. Як бачимо, для опису ключових об'єктів ситуації пропаганда використовуе термінологію не 3 нейтрального списку, а виключно зі списку негативного. Тобто негатив начебто бореться не з самою ситуацією, а 3 наявною в цій моделі світу символізаціею. При џьому обидві сторони описують свої військові перемоги і програші противника. Вони роблять це постійно вже не перший місяць, що також незрозуміло населенню через тривалий характер війни. Відомо, що за таких умов серед політиків i місцевого населення активізуються прихильники ведення війни, а не прихильники миру [9, с. 9].

Варто зазначити, що Росія часто використовувала пропагандистські прийоми, в яких емоційні компоненти були сильнішими за раціональні. У подібних випадках зайва емоційність часто блокуе раціональність. Крім того, російська пропаганда працюе із запрограмованими реакціями. Її формують так, щоб не залишити споживачеві права інформаційного вибору. При цьому Росія вкладає значні ресурси, щоб переконати у своїй правоті зарубіжного споживача новин, чого немає в Україні. С низка доволі авторитетних осіб у США i Свропі, які активно поширюють російську точку зору. Це відомі політологи, історики, журналісти, колишні дипломати, навіть актори. Вони можуть привернути на свій бік будьяку аудиторію [10]. На даний час Україна також розпочала роботу із зарубіжною аудиторією, включаючи і російську.

Інформаційна війна має на меті перетворити опонента на справжнього ворога, який $є$ жахливим вже самим фрактом свого існування. Росія переконалася в правильності власного вибору основного каналу для пропагандистського впливу на своє населення телебачення. Головною новинкою цієї інформаційної війни стала робота 3 віртуальними об'єктами. Цілком позбавлені реальності ряд віртуальних пропагандистських об'єктів, які використовує російське телебачення: 1) «Новоросія» - хоча б тому, що історично Донецька і Луганська там ніколи не було; 2) «ввічливі чоловічки» - людину 3 автоматом в руках навряд чи можна вважати ввічливою, хоча їі всі повинні слухати $\mathrm{i}$ 
накази виконувати; 3) проведення виборів під дулами автоматів навряд чи відповідає самому поняттю «виборів». Віртуальність у даному випадку вимагала заповнення власними символами та історією. Дослідники, наприклад, зазначають: «У Новоросії не існуе, ані історичної столиці, ані історичних кордонів. Кожен окреслює їі абстрактну територію на власний розсуд, залежно від політичної кон'юнктури і наявної франтазії» [11]. Російським політтехнологом довелося вигадати i прапор, й інші символи так званої «Новоросії» [12].

Особливістю інтенсивної російської пропагандистської компанії періоду «гібридної війни» стало так зване «переведення уваги». Відвернувши увагу від внутрішнього життя, економічних та політичних негараздів i

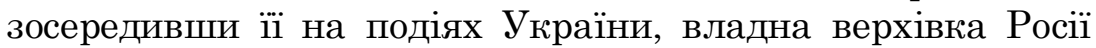
отримала зниження негативу стосовно своєї внутрішньої політики. Внутрішне життя Росії та їі громадян практично зникло $з$ екранів телевізорів. Навесні в 2014 р. новинах взагалі припинили розповідати і згадувати про те, що в Російській Федерації є окремі регіони й області, є посівні і надої, будівництво доріг і мостів, навіть таж таки «Сдина Росія». Після того, як Крим став окупованою російською територією, з телевізора цілком зникли проблеми, які хоча із великими перервами, але все - таки іноді з'являлися на телеекрані [14]. Варто підкреслити й те, що в Україні майже одночасно виникла подібна тенденція, що непатріотично згадувати владу в негативному контексті, адже точиться війна.

Російсько-українське протистояння характеризуеться ще однією особливістю. Відсутність активних бойових дій на фронті безпосередньо впливає на присутність відповідних слів та термінів у телеефірах. Так, 3 18 серпня 2014 р. майже зникли прізвище Гіркіна, терміни карателі і нелегітимна влада, хоча раніше Google подавав наступні цифри ї вживання: «російські агресори» - 14,9 тис.; «Київська хунта» - 796 тис.; «Каральна операція на Україні» - 127 тис.; «АТО в Україні» - 737 тис.; «укроп» - 725 тис.; «колорадо» 373 тис. [15]. Варто також виокремити декілька 
характеристик сформованого на сьогодні інформаційного простору України та назвати його слабкі ланки: 1) інформаційний хаос, який засвідчує, що на телеканалах й досі прослідковуеться ситуація функціонування безлічі суперечливих повідомлень, до яких додаються також повідомлення 3 російських соціальних мереж; 2) інформаційне «незавершення», що цілком дезорієнтує людину. Ось лише деякі запитання: хто стріляв на Майдані? Чому здали Крим? Хто був за це покараний?; 3)продукування тривожності, що викликає у людей негативні емоції, руйнує психіку, впливає на стан здоров'я (наукові розробки психологів доводять, що людина повинна отримувати 35\% - позитивних емоцій, $5 \%$ - негативних і $60 \%$ - нейтральних [4, с. 358]; 4) цілковита відсутність відповідальності, згідною з якою винні всі, а отже - ніхто. Жодне обвинувачення не спростовується але й не береться до уваги; 5) зміна героїки, яка відображена у новій військовій ситуації. Якщо колись до парламенту пішли дисиденти, то зараз там зібралися бойові командири. Вони входять до більшості партійних списків, хоча навряд чи готові до реальної парламентської роботи.

Україна в умовах «гібридної війни» вперше за роки незалежності зазнала найбільш серйозного випробування. Усі три пї простори - фрізичний, інформаційний та віртуальний - виявилися не готовими до цього. Але якщо висновки до фрізичного простору вже в основному зроблено, то таких висновків щодо двох інших просторів ніхто не зробив. Немає, наприклад, висновків щодо позиціонування України та Росії в міжнародному інформаційному полі, налагодженої інформаційної роботи на окупованих територіях, інформаційної роботи 3 примирення всередині України. Проте концентрація зусиль на чітких конкретних напрямах допоможе впоратися із поставленими завданнями. 
1. Требин М.П. Войны XXI века / М.П. Требин. - М.: АСТ; Мн: Харвест, 2005. - 608 с.

2. Парубій A. Війна Росії проти України і світу [Електронний ресурс] // Українська правда. Режим доступу: www.pravda.com.ua/2014/ 08/7034046/.

3. Стрельиов $\epsilon$. Сучасна війна у визначеннях Воєнної доктрини України // Національна безпека. - 2015. № 36. $-12-18$ вересня. - С. 12 .

4. Сенченко M.I. Латентна світова інформаційна війна / М.I. Сенченко. - К.: ФОП Стебеляк, 2014. $384 \mathrm{c}$.

5. Порошенко «розбомбив» Путіна. Президент України не залишив каменя на камені з промови Путіна на сесії Генасамблеї ООН // Високий замок. - 2015. № 107. - 1-7 жовтня. - С. 5.

6. Рущенко І.П. Російсько-українська гібридна війна: погляд соціолога / І.П. Рущенко. - Х.: ФОП Павленко О.І., 2015. - 268 с.

7. Аржаковський A. Розбрат України з Росією: стратегія виходу з піке. Погляд Свропи / Антуан Аржаковський. - Х.: Віват, 2015. - 256 с.

8. Почепцов I. Сучасні інформаційні війни / I. Почепщов. - К.: Вид. дім «Києво-Могилянська академія», 2015. - 497 с.

9. Клімкін П. План агресора: щоб «партія війни» перегризла горло "партії миру» // Високий замок. 2015. - № 113. - 15-21 жовтня. - С. 9.

10. К войне с Украиной Россия готовилась 11 лет, и она будет долгой [Електронний ресурс] / Илларионов. Режим доступу: http://www.facenews.ua /news/2014/ $255780 /$.

11. Клеть C. Что такое Новороссия и как с ней быть [Електронний ресурс]. - Режим доступу: www.pravda.com.ua/rus/articles/2014/08/15/7034916/.

12. Кудрин О. Флаги, гербы и лозунги: о PR - проколах авторов «Новороссии» [Електронний ресурс]. Режим доступу: sprotyv. info /ru/ news / 3694 - flagu gerby - i - lozungu - o - prokolax - avtorov - novorossii.

13. Каліновська O., К Криштопа О., Трохимчук В., Феденко Д. Неоголошена війна. Невідомі фракти і хроніки АТО / О. Каліновська, О. Криштопа, Є. Назаренко, В. Трохимчук, Д. Феденко. - Х.: Клуб сімейного дозвілля, 2015. $512 \mathrm{c}$.

14. Бородина A. Телевизор Олимпиады и Украины: рекорды пропаганды [Електронний ресурс]. - 
Режим доступу: www.forbes.ru/mneniya-opinion/ konkurentsia/261539-televizor-olimpiady-ukrainyrekordy-propagandy.

15. Ралов A. Карт-бланш. В информационном зазеркалье [Електронний ресурс]. - Режим доступу: www/ng.ru/ politics/ 2014-10-01/ 3 kartblansh.html.

Надійшла 20.05.2016 p.

Рецензент: В.С. Виздрик, доктор історичних наук, доцент, професор кафедри гуманітарних наук, Національна академія сухопутних військ імені гетьмана Петра Сагайдачного, м. Львів.

\section{Гетманчук М.П. \\ «ГИБРИДНАЯ ВОЙНА» РОССИИ ПРОТИВ УКРАИНЫ: ИНФОРМАЦИОННЫЙ АСПЕКТ}

Исследуется характер российско-украинской «гибридной войны». Не затрагивая военных и вооруженных аспектов конфликта, освещена информационная составляющая «гибридной войны», которая в рамках войн четвертого поколения стала одним из определяющих фракторов противостояния между агрессором и страной, подвергшейся нападению. Особый акцент сделан на исследовании: особенностей пропагандистских механизмов с обеих сторон росийско-украинского конфликта; сопоставления коммуникационно-пропагандистских возможностей сторон; работы с массовой аудиторией; ошибок информационной политики в период российско-украинского конфоликта.

Ключевые слова: российско-украинская война, «гибридная война», информационная война, смысловая война, информационные технологии.

\section{Hetmanchuk M. «HYBRID WAR» OF RUSSIA AGAINST UKRAINE: INFORMATION ASPECT}

The nature of the Russian-Ukrainian hybrid war is considered in the article. Leaving aside the purely military aspects and armed conflict highlighted information component of a hybrid war. As part of the fourth generation wars it was one of the determining factors of confrontation between the aggressor and the country has suffered. Particular emphasis is placed on research, advocacy mechanisms features on both sides of the Russian-Ukrainian conflict; comparison communicative outreach capacity of the parties; Work with a mass audience; Information Policy errors during the Russian-Ukrainian conflict.

Keywords: Russian-Ukrainian war, hybrid warfare, information technology, semantic war. 